\title{
Survei Kreativitas Guru Penjaskes Dalam Menghadapi Pembelajaran Secara Daring di Sekolah Menengah Pertama
}

\section{Survey on the Creativity of Physical Education Teachers in Facing Online Learning at State Junior High Schools}

\author{
Aprilyadi*, Meirizal Usra, Herri Yusfi \\ Pendidikan Jasmani dan Kesehatan, Fakultas Keguruan dan Ilmu Pendidikan, Universitas Sriwijaya, Jala Raya \\ Palembang - Prabumulih KM. 32 Inderalaya Ogan Ilir, Sumatera Selatan, 30862, Indonesia \\ e-mail: aprilyadi3121@gmail.com, meirizalusra@fkip.unsri.ac.id, herriyusfi@fkip.unsri.ac.id
}

\begin{abstract}
Abstrak
Penelitian ini bertujuan untuk mengetahui kreativitas guru pendidikan jasmani olahraga dan kesehatan dalam menghadapi pembelajaran secara daring mata pelajaran penjaskes (PJOK). Kreativitas diperlukan dalam melakukan sesuatu seperti proses pembelajaran, dalam proses pembelajaran kreativitas sangat diperlukan, seseorang guru yang tidak memiliki kreativitas dalam mengajar tidak mungkin menciptkan peserta didik yang kreatif dan inovatif selama proses pembelajaran. Jenis penelitian ini merupakan deskriftif kuantitatif dengan data persentase dan metode yang digunakan merupakan metode survei. Populasi penelitian ini adalah seluruh guru PJOK SMP Negeri seKecamatan Inderalaya Utara Kabupaten Ogan Ilir. Sampel terdiri dari kepala sekolah dan guru PJOK dengan jumlah 97 sampel. Teknik pengumpulan data yang digunakan adalah angket dan dokumentasi. Teknik analisis data yang digunakan yaitu analisisi statistik persentase dalam bentuk tabel frekuensi dan histrogram. Berdasarkan hasil penelitian yang diperoleh dari kreativitas guru PJOK dalam menghadapi pembelajaran secara daring, maka diketahui untuk persentase kreativitas guru PJOK 90,0\% dan untuk pembelajaran daring $90,1 \%$ Untuk keseluruhan indikator $90,2 \%$ hasil tersebut berarti termasuk dalam kategori baik untuk kriteria persentase kreativitas guru dalam menghadapi pembelajaran secara daring.
\end{abstract}

Kata kunci: Kreativitas, Guru PJOK, Pembelajaran Daring, Survei

\section{Abstract}

This study aims to determine the creativity of sports and health physical education teachers in dealing with online learning in physical education subjects (PJOK). Creativity is needed in doing something like the learning process, in the learning process creativity is needed, a teacher who does not have creativity in teaching is unlikely to create creative and innovative students during the learning process. This type of research is a quantitative descriptive with percentage data and the method used is a survey method. The population of this study were all teachers of PJOK of State Junior High Schools in North Inderalaya District, Ogan Ilir Regency. Researchers took other subject teachers, principals and PJOK teachers with a total of 97 samples. Data collection techniques used are questionnaires and documentation. The data analysis technique used is statistical analysis of percentages in the form of frequency tables and histograms. Based on the research results obtained from the creativity of PJOK teachers in dealing with online learning, it is known that the percentage of PJOK teachers' creativity is $90,0 \%$ and for online learning $90,1 \%$ For the overall indicator of 90,2\%, the result means that it is included in the good category for the criteria for the percentage of teacher creativity in dealing with online learning.

Keywords: Creativity, PJOK Teachers, Online Learning, Survey

corresponding author: aprilyadi3121@gmail.com

\section{Artikel Info:}

Submitted: 20/09/2021

Revised : 24/09/2021

Accepted : 02/11/2021

Published: 15/11/2021

\section{(ब) (1) optonactess}

Journal Coaching Education Sports is licensed under a Creatives Commons Attribution 4.0 International License. 


\section{A. Pendahuluan}

Pendidikan di Indonesia pada tahun 2020 berubah drastis akibat pandemi Coronavirus Diseases 2019 (Covid-19), bahkan di dunia yang mengakibatkan tidak efektifnya proses belajar mengajar secara tatap muka dan beralih ke penerapan pembelajaran dalam jaringan (daring) yang memanfaatkan system electronic learning (browsing, video call, chatting) (Susilo et al., 2020). Sejak menyebarnya virus Covid-19 yang menyebabkan masalah kesehatan yang sangat serius apabila seseorang mengalami penularan virus Covid-19 (Chan et al., 2020). Oleh karena itu pemerintah Indonesia menghimbau pembelajaran yang dilakukan secara tatap muka digantikan dengan pembelajaran secara daring (online) yang membuat banyaknya kekurangan dan kendala dalam pembelajaran (Hakim \& Mulyapradana, 2020). Dalam konsep teknologi pendidikan, pada model distancing learning (pembelajaran jarak jauh) yang menjadi awal pembelajaran online/daring, teknologi hanyalah sebuah alat (tools) (Hanifah Salsabila et al., 2020)

Pembelajaran daring adalah pemanfaatan jaringan internet dalam proses pembelajaran. Pembelajaran daring membuat peserta didik memiliki keleluasaan waktu belajar, dapat belajar kapanpun dan dimanapun (Endah
Wulantina, 2019). Peserta didik dapat berinteraksi dengan guru menggunakan beberapa teknologi aplikasi pendukung seperti classroom, video converence, telepon atau live chat, zoom maupun melalui whatsapp group (Firman \& Rahayu, 2020).

Pendidikan jasmani merupakan program pembelajaran yang memberikan perhatian yang seimbang dan memadai pada domain-domain pembelajaran, yaitu psikomotor, kognitif, dan afektif (Malik \& Rubiana, 2019). Pendidikan olahraga merupakan disiplin ilmu yang didominasi praktik pada aktivitas fisik dan sedikit teori (Fajar, 2017). Dalam kurikulum 2013 (K13) pendidikan olahraga dijenjang pendidikan SMP menyatu dalam mata pelajaran Pendidikan Jasmani Kesehatan dan Olahraga (PJOK) (Purnomo Adi Pratama et al., 2020). Sejalan dengan itu maka hakikat pendidikan jasmani mencakup semua unsur kebugaran, keterampilan gerakan fisik, kesehatan, permainan, olahraga, tari, dan rekreasi (Widodo, 2018).

Proses belajar mengajar selama masa pandemi Covid-19 mengunakan pembelajaran secara daring, hal ini mengakibatkan munculnya permasalahan baru seperti yang ditemui di lapangan yakni masih banyak siswa yang mengeluhkan tentang fasilitas belajar, 
kuota internet yang tidak sedikit, dan adapun masalah ganguan sinyal yang tidak stabil sehingga informasi yang disampaikan oleh guru tidak tersampaikan dengan baik kepada siswa sehingga mengakibatkan rendahnya kreatifitas siswa (Waspodo, 2020).

Kreativitas dapat diartikan kemampuan menanggapi dan memberikan jalan keluar segala pemecahan yang ada, kemampuan melibatkan diri pada proses penemuan untuk kemaslahatan kemampuan intelegensi gaya kognitif, dan kepribadian/motivasi, kemampuan untuk menghasilkan atau menciptakan sesuatu yang baru, maka dari itu kreativitas didasari dengan kelenturan (flexsibility), kelancaran (fluencely), kecakapan (smartly), dan kepandaian (intellegency) (Herlina et al., 2020)

Pembelajaran daring dapat menggunakan berbagai teknologi digital aplikasi seperti google classroom, video conference, zoom meeting, dan media whatsapp group serta juga aplikasi rumah belajar, telepon, dan lain-lainnya (Dewi, 2020). Dalam Pembelajaran daring merupakan pembelajaran yang menggunakan jaringan internet yang dilakukan secara online dengan memanfaatkan konektifitas, aksesibilitas, dan flektibilitas serta kemampuan untuk memunculkan berbagai jenis interaksi pembelajaran (Dewi, 2020). Pembelajaran daring adalah program penyelenggaraan kelas pembelajaran dalam jaringan untuk menjangkau kelompok target yang masif dan luas. Melalui jaringan, pembelajaran dapat diselenggarakan secara masif dengan peserta yang tidak terbatas (Herlina \& Suherman, 2020)

Distance learning model untuk mata pelajaran PJOK dengan collaborative approach bersama orang tua siswa menjadi solusi dan potensi pembelajaran pada sekolah dan wilayah yang tidak bisa menerapkan pembelajaran online yang terkendala oleh jaringan internet, sarana dan prasarana pendukung serta minimnya penguasaan guru dan siswa terhadap keterampilan pembelajaran online (Herlina \& Suherman, 2020). Manfaat pembelajaran daring yaitu meningkatkan mutu pendidikan dan pelatihan dengan memanfaatkan multimedia secara efektif dalam pembelajaran dan meningkatkan keterjangkauan yang bermutu melalui penyelenggaraan pembelajaran dalam jaringan serta menekan biaya penyelenggaraan yang bermutu melalui pemanfaatan sumber daya bersama (Mózo, 2017).

\section{B. Metode Penelitian}

Metode yang digunakan pada penelitian ini adalah penelitian deskriptif kuantitatif dengan pendekatan one shot 
case study. Analisis data bersifat

kuantitatif statistik dengan tujuan menguji hipotesis yang telah ditetapkan. Metode penelitian ini menggunakan metode survei, sedangkan pengumpulan datanya menggunakan angket atau kuesioner. Populasi pada penelitian ini adalah kepala sekolah, guru PJOK yang mengajar di SMP Negeri Se-Kecamatan Inderalaya Utara Kabupaten Ogan Ilir yang berjumlah 97 responden. Penelitian dilaksanakan di SMP Negeri Se-Kecamatan Inderalaya Utara Kabupaten Ogan Ilir yang berjumlah 7 sekolah menengah pertama.

\section{Hasil dan Pembahasan}

\section{Hasil}

Pada bagian ini membahas tentang persentase data yang telah dilakukan menggunakan IBM SPSS 25 dan excel, maka dapat dideskripsikan data hasil penelitian sebagai berikut:

Tabel 1. Pembelajaran

\begin{tabular}{cccc}
\hline Pernyataan & Frekuensi & Persentase & $\begin{array}{c}\text { Skor } \\
\text { Soal }\end{array}$ \\
\hline Sts & 0 & 0 & 0 \\
Ts & 0 & 0 & 0 \\
N & 5 & 5,2 & 15 \\
S & 37 & 38,1 & 148 \\
Ss & 55 & 56,7 & 275 \\
Total & 97 & 100,0 & 438 \\
\hline Dari tabel & 1 diatas diketahui & bahwa
\end{tabular}

pada indikator pembelajaran guru PJOK tetap memberikan pembelajaran secara daring sebanyak $56.7 \%$ responden menjawab sangat setuju dengan skor soal yang diperoleh sebesar 275, 38.1\% responden menjawab setuju dengan skor soal yang diperoleh sebesar 148 dan 5.2\% responden menjawab netral dengan skor soal yang diperoleh sebesar 15 .

\section{Tabel 2. Kesesuaian Materi}

Pembelajaran

\begin{tabular}{cccc}
\hline Pernyataan & Frekuensi & Persentase & $\begin{array}{c}\text { Skor } \\
\text { Soal }\end{array}$ \\
\hline Sts & 0 & 0 & 0 \\
Ts & 0 & 0 & 0 \\
N & 3 & 3,1 & 9 \\
S & 37 & 38,1 & 148 \\
Ss & 57 & 58,8 & 285 \\
Total & 97 & 100,0 & 448 \\
\hline
\end{tabular}

Dari tabel 2 diatas diketahui bahwa pelaksaan pembelajaran guru PJOK secara daring saat ini tetap memberikan pembelajaran sesuai RPP sebanyak $58.8 \%$ responden menjawab sengat setuju dengan skor yang diperoleh sebesar 285, 38.1\% responden menjawab setuju dengan skor yang diperoleh sebesar 148 dan $3.1 \%$ responden menjawab netral dengan skor soal yang diperoleh sebesar 9 .

\section{Tabel 3. Metode Pembelajaran}

\begin{tabular}{cccc}
\hline Pernyataan & Frekuensi & Persentase & $\begin{array}{c}\text { Skor } \\
\text { Soal }\end{array}$ \\
\hline Sts & 0 & 0 & 0 \\
Ts & 0 & 0 & 0 \\
N & 2 & 2,1 & 6 \\
S & 39 & 40,2 & 156 \\
Ss & 56 & 57,7 & 280 \\
Total & 97 & 100,0 & 442 \\
\hline
\end{tabular}


diperoleh sebesar 9.

Dari tabel 3 diatas diketahui bahwa pembelajaran daring dan pekerjaan rumah menjadi metode yang paling efektif untuk di terapkan guru PJOK dalam proses pembelajaran sebanyak $57.7 \%$ responden menjawab sangat setuju dengan skor soal yang diperoleh sebesar 280, 40.2\% responden menjawab setuju dengan skor soal yang diperoleh sebesar 156 dan $2.1 \%$ responden menjawab netral dengan skor soal yang diperoleh sebesar 6 .

\section{Tabel 4. Media Pembelajaran}

\begin{tabular}{cccc}
\hline Pernyataan & Frekuensi & Persentase & $\begin{array}{c}\text { Skor } \\
\text { Soal }\end{array}$ \\
\hline Sts & 0 & 0 & 0 \\
Ts & 0 & 0 & 0 \\
N & 3 & 3,1 & 9 \\
S & 41 & 42,3 & 164 \\
Ss & 53 & 54,6 & 265 \\
Total & 97 & 100 & 438 \\
\hline
\end{tabular}

Dari tabel 4 diatas diketahui bahwa media seperti Whatsapp Grup, Google Classroom dan aplikasi pendukung lainnya menjadi media pembelajaran yang sangat berguna bagi guru PJOK untuk tetap memberikan pembelajaran secara daring sebanyak $54.6 \%$ responden menjawab sangat setuju dengan skor soal yang diperoleh sebesar 265, 42.3\% responden menjawab setuju dengan skor soal yang diperoleh sebesar 164 dan 3.1\% responden menjawab netral dengan skor soal yang

\section{Tabel 5. Partisipasi Peserta Didik}

\begin{tabular}{cccc}
\hline Pernyataan & Frekuensi & Persentase & $\begin{array}{c}\text { Skor } \\
\text { Soal }\end{array}$ \\
\hline Sts & 0 & 0 & 0 \\
Ts & 0 & 0 & 0 \\
N & 5 & 5,2 & 15 \\
S & 39 & 42,3 & 164 \\
Ss & 53 & 54,6 & 265 \\
Total & 97 & 100 & 444 \\
\hline
\end{tabular}

Dari tabel 5 diatas diketahui bahwa dalam pelaksaan pembelajaran secara daring untuk pembelajaran PJOK peserta didik sangat antusias dan berpartisipasi dengan mengikuti pembelajaran yang inovatif dan kreatif sebanyak $54.6 \%$ responden menjawab sangat setuju dengan skor soal yang diperoleh sebesar 265, $40.2 \%$ responden menjawab setuju dengan skor soal yang diperoleh sebesar 164 dan $5.2 \%$ responden menjawab netral dengan skor soal yang diperoleh sebesar 15 .

\section{Tabel 6. Proses Pembelajaran}

\begin{tabular}{cccc}
\hline Pernyataan & Frekuensi & Persentase & $\begin{array}{c}\text { Skor } \\
\text { Soal }\end{array}$ \\
\hline Sts & 0 & 0 & 0 \\
Ts & 0 & 0 & 0 \\
N & 8 & 8,2 & 24 \\
S & 34 & 35,1 & 136 \\
Ss & 55 & 56,1 & 275 \\
Total & 97 & 100 & 433 \\
\hline
\end{tabular}

Dari tabel 6 diatas diketahui bahwa proses pembelajaran guru PJOK dalam memberikan pembelajaran secara daring melalui tutorial dan powerpoint agar 
pembelajaran menarik dan kreatif sebanyak $56.7 \%$ responden menjawab sangat setuju dengan skor soal yang diperoleh sebesar $275,35.1 \%$ responden menjawab setuju dengan skor soal yang diperoleh sebesar 136 dan $8.2 \%$ responden menjawab netral dengan skor soal yang diperoleh sebesar 24 .

Tabel 7. Kreativitas Guru

\begin{tabular}{cccc}
\hline Pernyataan & Frekuensi & Persentase & $\begin{array}{c}\text { Skor } \\
\text { Soal }\end{array}$ \\
\hline Sts & 0 & 0 & 0 \\
Ts & 0 & 0 & 0 \\
N & 15 & 15,5 & 45 \\
S & 40 & 41,1 & 160 \\
Ss & 42 & 43,3 & 210 \\
Total & 97 & 100 & 415 \\
\hline
\end{tabular}

Dari tabel 7 diatas diketahui bahwa peserta didik berkembang dengan inovasi baru yang diberikan guru PJOK dengan pembelajaran yang inovatif dan kreatif sebanyak $43.3 \%$ responden menjawab sangat setuju dengan skor soal yang diperoleh sebesar 210, $41.2 \%$ responden menjawab setuju dengan skor soal yang diperoleh sebesar 160 dan $15.2 \%$ responden menjawab netral dengan skor soal yang diperoleh sebesar 45 .

\section{Tabel 8. Sistem dan Proses Penilaian}

\begin{tabular}{cccc}
\hline Pernyataan & Frekuensi & Persentase & $\begin{array}{c}\text { Skor } \\
\text { Soal }\end{array}$ \\
\hline Sts & 0 & 0 & 0 \\
Ts & 0 & 0 & 0 \\
N & 2 & 2,1 & 6 \\
S & 41 & 42,3 & 164 \\
Ss & 54 & 55,7 & 270 \\
Total & 97 & 100 & 440 \\
\hline
\end{tabular}

Dari Tabel 8 diatas diketahui bahwa sistem dan proses penilaian peserta didik melalui forum diskusi kesesuaian pengumpulan tugas dan ujian menjadi sistem penilaian guru PJOK dalam pelaksanan pembelajaran daring sebanyak $55.7 \%$ responden menjawab sangat setuju dengan skor soal yang diperoleh sebesar $270,42.3 \%$ responden menjawab setuju dengan skor soal yang diperoleh sebesar 164 dan $2.1 \%$ responden menjawab netral dengan skor soal yang diperoleh sebesar 6 .

\section{Tabel 9. Penilaian}

\begin{tabular}{cccc}
\hline Pernyataan & Frekuensi & Persentase & $\begin{array}{c}\text { Skor } \\
\text { Soal }\end{array}$ \\
\hline Sts & 0 & 0 & 0 \\
Ts & 0 & 0 & 0 \\
N & 2 & 2,1 & 6 \\
S & 39 & 40,2 & 156 \\
Ss & 56 & 55,7 & 280 \\
Total & 97 & 100 & 442 \\
\hline
\end{tabular}

Dari tabel 9 diatas diketahui pelaksaan penilaian peserta didik untuk saat ini terlaksana dengan baik melalui pembelajaran PJOK secara daring sebanyak $57.7 \%$ responden menjawab sangat setuju dengan skor soal yang diperoleh sebesar 280, 40.2\% responden menjawab setuju dengan skor soal yang diperoleh sebesar156 dan $2.1 \%$ responden menjawab netral dengan skor soal yang diperoleh sebesar 6 .

Tabel 10. Kendala Pembelajaran

\begin{tabular}{cccc}
\hline Pernyataan & Frekuensi & Persentase & $\begin{array}{c}\text { Skor } \\
\text { Soal }\end{array}$ \\
\hline Sts & 0 & 0 & 0 \\
Ts & 0 & 0 & 0
\end{tabular}




\begin{tabular}{cccc}
\hline $\mathrm{N}$ & 0 & 0 & 0 \\
$\mathrm{~S}$ & 25 & 25,8 & 75 \\
$\mathrm{Ss}$ & 72 & 74,3 & 360 \\
Total & 97 & 100 & 435 \\
\hline
\end{tabular}

Dari tabel 10 diatas diketahui bahwa kendala pembelajaran belum mengguasai penggunaan media online, kesulitan dalam mengakses internet dan kurangnya pengawasan orang tua siswa belajar dirumah menjadi kendala utama bagi guru
PJOK dalam pelaksaan pembelajaran secara daring sebanyak $74.2 \%$ responden menjawab sangat setuju dengan skor soal yang di peroleh sebesar 360 dan $25.8 \%$ responden menjawab setuju dengan skor soal yang diperoleh sebesar 75 .

Tabel 11. Analisis Data

\begin{tabular}{|c|c|c|c|c|c|}
\hline Variabel & Indikator & $\begin{array}{l}\text { Skor } \\
\text { Soal }\end{array}$ & $\begin{array}{c}\text { Skor } \\
\text { Maksimal }\end{array}$ & Persentase \% & $\begin{array}{c}\text { Jumlah \% Rata- } \\
\text { rata }\end{array}$ \\
\hline \multirow{7}{*}{$\begin{array}{c}\text { Kreativitas Guru } \\
\text { PJOK }\end{array}$} & 1. Pembelajaran & 438 & 485 & 90,3 & \multirow{7}{*}{90,0} \\
\hline & $\begin{array}{l}\text { 2. Kesesuaian Materi } \\
\text { Ajar }\end{array}$ & 448 & 485 & 92,3 & \\
\hline & 3. Metode Pembelajaran & 442 & 485 & 91,1 & \\
\hline & 4. Media Pembelajaran & 438 & 485 & 90,3 & \\
\hline & $\begin{array}{l}\text { 5. Partisipasi Peserta } \\
\text { Didik }\end{array}$ & 444 & 485 & 91,5 & \\
\hline & 6. Proses Pembelajaran & 433 & 485 & 89,2 & \\
\hline & 7. Kreativitas Guru & 415 & 485 & 85,5 & \\
\hline \multirow{3}{*}{$\begin{array}{l}\text { Pembelajaran } \\
\text { Daring }\end{array}$} & $\begin{array}{l}\text { 8. Sistem dan Proses } \\
\text { Penilaian }\end{array}$ & 440 & 485 & 90,7 & \multirow{3}{*}{90,1} \\
\hline & 9. Penilaian & 442 & 485 & 91,1 & \\
\hline & $\begin{array}{l}\text { 10. Kendala } \\
\text { Pembelajaran }\end{array}$ & 435 & 485 & 89,6 & \\
\hline \multicolumn{5}{|c|}{ JUMLAH RATA-RATA KESELURUHAN } & 90,2 \\
\hline
\end{tabular}

\section{Pembahasan}

\section{Tabel 12. Kategori Persentase Skor}

\begin{tabular}{ll}
\hline \multicolumn{1}{c}{ Persentase } & \multicolumn{1}{c}{ Kategori } \\
\hline $0 \%-19,99 \%$ & Sangat Kurang Baik \\
$20 \%-39,99 \%$ & Kurang Baik \\
$40 \%-59,99 \%$ & Cukup \\
$60 \%-79,99 \%$ & Baik \\
$80 \%-100 \%$ & Sangat Baik
\end{tabular}

(Sumber: Fitriyani dkk, 2020)
Survei kreativitas guru pendidikan jasmani olahraga dan kesehatan (PJOK) dalam menghadapi pembelajaran secara daring di SMP Negeri se-Kecamatan Inderalaya Utara Kabupaten Ogan Ilir. Kreativitas diartikan sebagai kemampuan untuk menciptakan suatu produk baru, baik yang benar- benar baru sama sekali maupun yang merupakan modifikasi atau 
perubahan dengan mengembangkan halhal yang sudah ada (Pentury, 2017). Bahkan menurut (Wicaksono, 2019) guru yang kreativitasnya baik akan membuat proses pembelajaran menjadi lebih menarik. Sedangkan pendidikan jasmani adalah fase dari program pendidikan keseluruhan yang memberikan kontribusi terutama melalui pengalaman gerak untuk pertumbuhan dan perkembangan secara utuh untuk tiap peserta didik (Yahya et al., 2020). Pendidikan jasmani adalah sebuah program pembelajaran yang memberikan perhatian yang proporsional dan memadai pada domain-domain pembelajaran yaitu psikomotor, kognitif, serta afektif (Sahabuddin et al., 2020). Pembelajaran daring atau E-Learning merupakan pembelajaran yang menggunakan jaringan internet secara online yang memiliki program-program khusus untuk pelaksanaan pembelajaran dan pengiriman materi pembelajaran dengan menggunakan berbagai teknologi digital aplikasi (Fitriyani et al., 2020). Menurut (Dewi, 2020) Pembelajaran daring dapat menggunakan berbagai teknologi digital aplikasi seperti google classroom, video conference, zoom meeting, dan media whatsapp group serta juga aplikasi rumah belajar, telepon, dan lain-lainnya.

Sesuai dengan rumusan masalah tujuan penelitian dan hasil penelitian tentang survei kreativitas guru pendidikan jasmani olahraga dan kesehatan (PJOK) dalam menghadapi pembelajaran secara daring mata pelajaran penjaskes, maka diketahui kreativitas mengajar guru pendidikan jasmani olahraga dan kesehatan (PJOK) dalam menghadapi pembelajaran secara daring mata pelajaran penjaskes di SMP Negeri se-Kecamatan Inderalaya Utara Kabupaten Ogan Ilir untuk nilai persentase kreativitas guru PJOK sebesar 90,0\% masuk dalam kategori cukup, untuk hasil nilai persentase pembelajaran daring $90,1 \%$ masuk dalam kategori baik dan untuk nilai persentase keseluruhan kreativitas guru PJOK dalam menghadapi pembelajaran secara daring menunjukkan persentase hasil 90,2\% masuk dalam kategori sangat baik.

Hasil indikator keseluruhan dengan kategori sangat baik tersebut tidak lepas dari beberapa aspek yang mempengaruhi antara lain semangat mengajar guru, pengetahuan, keinginan tinggi untuk beradaptasi dengan keadaan sekarang dan lain-lain. Walaupun pembelajaran untuk saat ini dilakukan dalam keadaan pembelajaran secara daring guru PJOK yang mengajar di SMP Negeri seKecamatan Inderalaya Utara Kabupaten Ogan Ilir dapat menyesuaikan diri dalam menghadapi pembelajaran secara daring untuk saat ini. Dengan pembelajaran yang menarik, inovatif dan kreatif membuat pembelajaran penjaskes tetap terlaksana 
meskipun dalam keadaan pandemi covid19 dengan baik sesuai dengan kurikulum yang ada pada saat ini, hal ini dibuktikan dengan tetap terlaksananya pembelajaran penjaskes sesuai kurikulum dan pengambilan penilaian peserta didik walapun banyak nya kendala dalam melakukan pembelajaran secara daring.

\section{Kesimpulan}

Berdasarkan pembahasan dan uraian di atas dapat disimpulkan bahwa survei kreativitas guru pendidikan jasmani olahraga (PJOK) dalam menghadapi pembelajaran secara daring di SMP Negeri se-Kecamtan Inderalaya Utara Kabupaten Ogan Ilir sudah sangat baik. Hal ini terbukti dari hasil penelitian keseluruhan yang menunjukkan persentase 90,2 \% untuk kategori sangat baik

\section{Daftar pustaka}

Chan, J. F.-W., Kok, K.-H., Zhu, Z., Chu, H., To, K. K.-W., Yuan, S., \& Yuen, K.-Y. (2020). Genomic characterization of the 2019 novel human-pathogenic coronavirus isolated from a patient with atypical pneumonia after visiting Wuhan. Emerging Microbes \& Infections, 9(1), 221-236. https://doi.org/10.1080/22221751.202 $\underline{0.1719902}$
Dewi, W. A. F. (2020). Dampak COVID19 terhadap Implementasi Pembelajaran Daring di Sekolah Dasar. Edukatif: Jurnal Ilmu Pendidikan, 2(1), 55-61. https://doi.org/10.31004/edukatif.v2i1 $\underline{.89}$

Endah Wulantina, S. M. (2019). Persepsi Peserta Didik terhadap Metode Blended Learning dengan Google Classroom. Jurnal Inovasi Matematika.

https://doi.org/10.35438/inomatika.v1 $\underline{\mathrm{i} 2.156}$

Fajar, M. (2017). Peranan Intelegensi Terhadap Perkembangan

Keterampilan Fisik Motorik Peserta Didik Dalam Pendidikan Jasmani. Multilateral Jurnal Pendidikan Jasmani Dan Olahraga, 16(1), 5866.

https://doi.org/10.20527/multilateral.v $\underline{16 i 1.3664}$

Firman, F., \& Rahayu, S. (2020). Pembelajaran Online di Tengah Pandemi Covid-19. Indonesian Journal of Educational Science (IJES), $\quad 2(2), \quad 81-89$. https://doi.org/10.31605/ijes.v2i2.659 Fitriyani, Y., Fauzi, I., \& Sari, M. Z. (2020). Motivasi Belajar Mahasiswa Pada Pembelajaran Daring Selama Pandemik Covid-19. Jurnal 
Survei Kreativitas Guru Pendidikan Jasmani Olahraga dan Kesehatan Dalam Menghadapi Pembelajaran Secara Daring di Sekolah Menengah Pertama

E-ISSN: 2722-3450 P-ISSN:2775-3808

Kependidikan: Jurnal Hasil

Penelitian Dan Kajian Kepustakaan

Di, $\quad$ 6(2), 165-175.

https://doi.org/10.23917/ppd.v7i1.109 $\underline{73}$

Hakim, M., \& Mulyapradana, A. (2020).

Pengaruh Penggunaan Media Daring dan Motivasi Belajar Terhadap Kepuasan Mahasiswa Pada Saat Pandemik Covid-19. Widya Cipta: Jurnal Sekretari Dan Manajemen. https://doi.org/10.31294/widyacipta.v $\underline{4 \mathrm{i} 2.8853}$

Hanifah Salsabila, U., Irna Sari, L., Haibati Lathif, K., Puji Lestari, A., \& Ayuning, A. (2020). Peran Teknologi Dalam Pembelajaran Di Masa Pandemi Covid-19. Al-Mutharahah: Jurnal Penelitian Dan Kajian Sosial Keagamaan, $\quad$ 17(2), 188-198. https://doi.org/10.46781/al-

mutharahah.v17i2.138

Herlina, Erisna, \& Fitria, H. (2020).

Pengembangan Kreativitas Inovatif

Melalui Pembelajaran Digital.

Prosiding Seminar Nasional

Pendidikan Program Pascasarjana

Universitas Pgri Palembang, 406415.

https://doi.org/10.31004/edukatif.v2i1 $\underline{.89}$

Herlina, H., \& Suherman, M. (2020).

Potensi Pembelajaran Pendidikan

Jasmani Olahraga Dan Kesehatan
(Pjok) Di Tengah Pandemi Corona Virus Disease (Covid)-19 Di Sekolah Dasar. Tadulako Journal Sport Sciences And Physical Education, 8(1), 1-7. http://jurnal.untad.ac.id/jurnal/index.p $\underline{\mathrm{hp} / \mathrm{PJKR} / \mathrm{article} / \mathrm{view} / 16186}$

Malik, A. A., \& Rubiana, I. (2019). Kemampuan Teknik Dasar Bola Basket: Studi Deskriptif Pada Mahasiswa. Journal of SPORT (Sport, Physical Education, Organization, Recreation, and Training), 3(2), 79-84. https://doi.org/10.37058/sport.v3i2.12 $\underline{38}$

Mózo, B. S. (2017). Implementasi Zoom, Google Classroom, Dan Whatsapp Group Dalam Mendukung Pembelajaran Daring (Online) Pada Mata Kuliah Bahasa Inggris Lanjut. Journal of Chemical Information and Modeling.

https://doi.org/10.1017/CBO9781107 $\underline{415324.004}$

Pentury, H. J. (2017). Pengembangan Kreativitas Guru dalam Pembelajaran Kreatif Pembelajaran Bahasa Inggris. Jurnal Ilmu Kependidikan, 4(3), 265272.

https://doi.org/10.30998/fjik.v4i3.192 3.g1574

Purnomo Adi Pratama, Budiman Agung Pratama, Setyo Harmono, \& http://ejurnal.ubharajaya.ac.id/index.php/JCESPORTS 
Septyaning Lusianti. (2020). Survei Implementasi Pembelajaran

Pendidikan Jasmani Berdasarkan

Kurikulum 2013 Di SMP Se

Kecamatan Kertosono. Journal

Coaching Education Sports, 1(2), 6370.

https://doi.org/10.31599/jces.v1i2.334

Sahabuddin, Hakim, H., \& Binsar, A. R.

(2020). Analisis Kinerja Guru

Pendidikan Jasmani terhadap Motor

Ability dan Hasil Belajar Siswa

Sekolah Dasar. Journal Coaching

Education Sports, 1(1), 37-50.

https://doi.org/10.31599/jces.v1i1.84

Susilo, A., Rumende, C. M., Pitoyo, C.

W., Santoso, W. D., Yulianti, M.,

Sinto, R., Singh, G., Nainggolan, L.,

Nelwan, E. J., Khie, L., Widhani, A.,

Wijaya, E., Wicaksana, B., Maksum,

M., Annisa, F., Jasirwan, O. M., \&

Yunihastuti, E. (2020). Coronavirus

Disease 2019: Tinjauan Literatur

Terkini Coronavirus Disease 2019 :

Review of Current Literatures. Jurnal

Penyakit Dalam Indonesia, 7(1), 45-

67.

https://doi.org/10.7454/jpdi.v7i1.415

Waspodo, M. (2020). Pembelajaran Daring

di Masa Pandemi Covid -19 Komang.

In COVID-19: Perspektif Pendidikan

(Issue October, p. 220).

Wicaksono, G. H. (2019). Kreativitas Guru
Penjas Terhadap Proses Pembelajaran

Penjas Di Sekolah Menengah

Pertama negeri Sekecamatan

Kebumen Kabupaten Kebumen 2018.

Jurnal Pendidikan Kesehatan

Rekreasi, 5(2), 95-100.

https://doi.org/10.5281/zenodo.33429

$\underline{90}$

Widodo, A. (2018). Makna Dan Peran

Pendidikan Jasmani Dalam

Pembentukan Insan. Jurnal Motion,

9(1), 53-60.

https://www.researchgate.net/publicat

ion/329442726_MAKNA_DAN_PE

RAN_PENDIDIKAN_JASMANI_D

ALAM_PEMBENTUKAN_INSAN_

YANG_MELEK JASMANIAHTER

-LITERASI_JASMANIAHNYA

Yahya, R., Kurniawan, F., Effendi, R., Studi, P., Jasmani, P., Singaperbangsa, U., \& Ronggowaluyo, J. H. S. (2020). Penggunaan Pembelajaran Cooperative Learning permainan Bola Voli Dalam Meningkatkan Hasil Passing. Journal Coaching Education Sports, $\quad 1(2), \quad$ 105-114. https://doi.org/10.31599/jces.v1i2.366 